\title{
Современные подходы к введению прикорма у здоровых детей первого года жизни, находящихся на грудном вскармливании
}

\author{
Ганиева Г. ${ }^{1}$, Исмайлова Ш. ${ }^{2}$ \\ 1 Азербайджанский Медииинский Университет \\ 2 Центр Общественного Здравоохранения и Реформ
}

Абстракт. Продолжительное грудное вскармливание и правильно организованное последующее питание ребенка являются одними из самых важных и основополагающих факторов профилактики неинфекционных заболеваний, т.н. болезней цивилизации - ожирения, сахарного диабета и др. Как правило, переход от исключительно грудного вскармливания к кормлению обычными продуктами питания, употребляемыми всей семьей охватывает период в возрасте от 6 до 18-24 месяцев. Расширение рациона питания ребенка вызвано необходимостью дополнительного получения энергии и пищевых веществ (белков, жиров, углеводов, минеральных элементов и витаминов, пищевых волокон), поступление которых только с грудным молоком или искусственной смесью становится недостаточным.

Ключевые слова: кормление, ребенок, пищевой рацион.

Введение. Основная цель прикорма состоит в том, чтобы обеспечить ребенку дополнительное количество энергии и приучить ребенка к более густой пище. А поскольку желудок у него еще невелик, то при калорийности ниже, чем у грудного молока ребенок будет терять в энергии и пищевых веществах. Поэтому продукты для прикорма должны иметь высокую плотность энергии и микроэлементов. Слишком жидкая каша, бульон, соки и тому подобные продукты не будут эффективны в качестве прикорма.

В возрасте 6-8 месяцев в дополнение к грудному молоку ребенку ежедневно требуются дополнительно 200 ккал с прикормом, в возрасте 911 месяцев - 300 ккал. Грудное молоко в течение всего периода введения прикорма должно оставаться главным видом пищи, потребляемой грудным ребенком.

Когда вводить прикорм ребенку, находящемуся на исключительно грудном вскармливании?

Сроки введения прикорма, а также введение отдельных продуктов до сегодняшнего дня вызывают наибольшие споры. В рекомендациях Американской Педиатрической Академии указан возраст «примерно с 6 мес.». Европейское региональное бюро ВОЗ рекомендует, «чтобы все дети до 6 мес. находились только на грудном вскармливании», добавляя при этом «или хотя бы до 4 мес.». К возрасту 6 месяцев у ребенка созревает нервно-мышечная координация, достаточная для успешного поглощения полутвердой пищи, начинают прорезываться зубы. Формируется ферментативная система пищеварительного тракта, достаточная для переваривания крахмала, белков и жиров, содержащихся в немолочной пище (овощное или фруктовое пюре, печенье).

Негативные последствия может иметь как раннее, так позднее введение прикорма детям первого года жизни. Слишком раннее введение прикорма может вызвать диспептические заболевания и пищевые аллергии. Более того, исследованиями доказано, что прикорм ранее 6 месяцев дает более высокий риск развития железодефицитной анемии ${ }^{1,2}$. Если же прикорм вводится слишком поздно, это ведет к дефициту питательных веществ и задержке роста.

\section{Признаки готовности к вводу прикорма:}

- удвоение веса с момента рождения

- держит головку и сидит с поддержкой

- угасание выталкивающего рефлекса - если ребенку попадает что-то в ротик, он не стремится тут же вытолкнуть это языком

- ребенок может осознанно отворачиваться от ложки, если предложенный продукт не понравился

- открывает ротик, когда подносят ложку с едой

- ребенок чаще требует грудь

- ребенок интересуется едой, которую едят взрослые, тянется ручками

Одного-двух признаков из этого списка еще недостаточно для ввода прикорма: должны проявиться все. 


\section{Ребенок готов к новым вкусам если:}

1. демонстрирует нравиться ему пища или нет

2. начинает жевать

3. может формировать пищевой комок

4. плотно сжимает губы, если не хочет есть

5. двигает верхней губой, чтобы приспособиться к ложечке

Первыми вводимыми продуктами прикорма являются каши безмолочные (рисовая, гречневая кукурузная, пшеничная), овощные пюре (кабачок, цветная капуста, брокколи, тыква, морковь), мясные пюре. При дефиците массы тела, учащенном стуле предпочтение в качестве первого прикорма отдается каше, при избыточной массе тела, запорах овощному пюре. Важно, чтобы младенцы получали правильный и безопасный прикорм в достаточных количествах для обеспечения надлежащего перехода от грудного вскармливания к питанию обычными пищевыми продуктами ${ }^{3,4,5}$.

Первой предложенной ребенку пищей должны быть протёртые, пюреобразные продукты, состоящие из одного ингредиента мягкой консистенции без добавления сахара, соли или специй.

Каши - наиболее энергоемкий прикорм (каши домашнего приготовления или каши растворимые)

- каши, с которых начинается прикорм, должны быть безмолочными и безглютеновыми (гипоаллергенными): это рис, гречка, кукуруза, пшено, которые не содержат глютен - растительный белок, часто вызывающий аллергическую реакцию. После введения безглютеновых можно вводить другие каши (овсяная, пшеничная), а также - мультизлаковые. Наиболее ценные по составу микроэлементов - овсянка, гречка.

- каши промышленного производства, предпочтительнее каш домашнего приготовления для профилактики железодефицитной анемии, поскольку они обогащены железом, кальцием, цинком, йодом, в которых у ребенка возрастает в этот период потребность. Предпочтительны растворимые каши, которые нуждаются только в разведении и готовы к употреблению без варки

- если ребенок не хочет, есть безмолочную кашу, можно развести ее грудным молоком или искусственной смесью
- начинают вводить прикорм с одной чайной ложки, постепенно увеличивая до полного объема каждый новый вид каши, желательно вводить постепенно с интервалом в одну неделю.

Овощные пюре - источник сложных углеводов, органических кислот, калия, железа и пищевых волокон, включая пектины

- начинать вводить овощные пюре надо в первую очередь по сезону. Можно использовать пюре фабричного приготовления

- наилучший порядок введения овощей с нежной клетчаткой: цветная капуста, кабачок, брокколи, тыква, морковь

- смешивать разные виды овощей можно только тогда, когда ребенок их попробует по отдельности

- овощи лучше готовить на пару и размять до пюреобразной массы

Как повысить калорийность каш (или овощных пюре):

- готовить с использованием меньшего количества воды и делать более густую кашу

- заменять большую часть воды (или всю воду) грудным молоком или искусственной смесью

- добавлять в густую кашу (овощное пюре) растительное масло (например, оливковое) или топленое сливочное (не более одной чайной ложки), если объем каши 100 г и выше.

Мясо, птица, рыба, печень - для поддержания нормального уровня железа мясо животных добавляют к овощным пюре, кашам и дают в виде пюре. Допустимый объем мясного пюре: до 8 месяцев - 30 г/сутки, с 8 месяца - 50 г/сутки, с 9 месяца в среднем 60-70 г/сутки. Можно использовать: индейку, постную говядину, телятину, ягнятину, курицу. Следует избегать жирных сортов мяса: баранины, гусятины, утятины. Красное мясо - 1 раз в неделю, белое мясо - 2 раза в неделю, рыба - 2 раза в неделю.

Фруктовые пюре - целесообразно вводить только после того, как уже введены - каши, овощные пюре, мясо. Начинать введение лучше с яблочного, грушевого, сливового пюре с 1 чайной 
ложки постепенно увеличивая объем. Начиная с 9 месяцев у большинства детей уже есть прорезанные зубы, и они могут грызть кусочки фруктов. Фрукты даются в качестве перекуса. В день можно давать около 50-60 грамм фруктов, к году доводя до 100 г.

Цельное коровье молоко. Если ребенок находится на полноценном грудном вскармливании цельное коровье молоко, не рекомендуется до 1 года. Потому что: 1) оно может снизить и даже вытеснить потребление грудного молока; 2) в коровьем молоке низкое содержание железа; 3) оно может вызвать желудочно-кишечное кровотечение, особенно в возрасте до 6 месяцев; 4) в нем выше содержание белков и натрия - в 3-4 раза, чем в грудном молоке; 5) оно способствует развитию аллергии. В случае, если грудного молока недостаточно или мама хочет прекратить кормление грудью, то лучше использовать искусственные адаптированные смеси ${ }^{7}$.

Жидкость. Необходимость в жидкости возникает, только когда ребенок получает уже более или менее значимые порции прикорма (50 г и более). Между приемами пищи можно предложить ребенку попить обычную питьевую воду из чашки или с ложки (ни в коем случае из бутылки) из расчета 15-20 мл/кг/сутки, но если ребенок отказывается - настаивать не нужно. Для допаивания нельзя предлагать компоты, чаи и другие жидкости, имеющие сладкий или необычный для ребёнка вкус.

Фруктовые соки - согласно современной точке зрения их целесообразно вводить не ранее 10 месяцев после того, как уже введены - каша, овощное пюре, мясо, фрукты, кисломолочные продукты. В этом случае соки начинают играть роль стимуляторов аппетита, причем количество не должно превышать 50-60 мл в сутки, доходя к году до 100 мл (причем вначале их лучше разбавлять с водой). Необходимо следить, чтобы они не вытесняли грудное молоко. Эта позиция существенно отличается от ранее существовавших представлений о необходимости раннего введения в рацион питания грудного ребенка фруктовых соков.

\section{Этапы прикорма}

Первый этап: с 6-7 месяцев. На этом этапе основная цель состоит в том, чтобы ребенок попробовал вкус другой пищи и научился есть с ложки. В это время ему предлагается очень небольшое количество прикорма, всего одна-две чайные ложки за раз и всего один-два раза в день. При этом ребеноку нужно время, чтобы научиться губами снимать пищу с ложки и перемещать ее внутри рта, поэтому часть пищи может вываливаться изо рта это еще не значит, что ребенку не нравится еда.

- Основным источником получения энергии является грудное молоко, а для «искусственников» - искусственная смесь

- Кормление грудью при этом продолжается по требованию, а смесь дается в тех же количествах и с тем же интервалом, что и раньше

- Пища, которую получает ребенок на этом этапе - измельченные и размятые продукты, каши (энергоемкий прикорм), мясные и овощные пюре, состоящие из одного ингредиента, мягкой консистенции, без добавления сахара, соли или острых приправ. Это может быть как монокомпонентное пюре или детская каша промышленного производства, так и приготовленная дома еда: размятый рис, мягкая густая каша из гречки, овощное пюре, мясное пюре.

- Для более мягкого вкуса и лучшего усвоения можно добавить в пищу для ребенка сцеженное грудное молоко или детскую смесь

- Частота приема 1-2 раза вдень.

Второй этап: 7-8 месяцев. Когда ребенок может не только сидеть без поддержки, но и переносить предметы (например, ложку) из одной руки в другую - можно давать уже более густую пищу и добавлять новые оттенки вкуса.

- Кормление грудью продолжается при этом по требованию, но надо помнить, что нередко ребенок в это время начинает просить грудь реже

- Чтобы количество грудного молока, необходимое ребенку, не уменьшилось, предлагать прикорм после непродолжительного кормления грудью, и докармливать после прикорма

- Пища этого этапа - хорошо проваренные овощные, фруктовые пюре, проваренное до мягкой консистенции, измельченное мясо, различные зерновые продукты. В небольших количествах «ознакомительно» с 8 месяцев можно вводить бобовые. Причем пюре из бобовых однородной консистенции не вводится самостоятельно, а только в составе пюре из привычных овощей, мяса. По 0,5 ч. ложки. Сахар и соль по-прежнему не использовать. Частота приема пищи 2-3 
раза в день, ребенок съедает понемногу, но уже из более широкого диапазона продуктов.

Третий этап: 8-10 месяцев. Время постигать новые вкусовые оттенки, время учиться справляться с небольшими кусочками пищи. Можно не только кормить с ложки, но и предлагать ребенку такую еду, которую он может сам взять пальцами: ломтики фруктов, кусочки сыра или морковки. Поскольку в этом возрасте у ребенка высокий риск подавиться, эти продукты нужно или термически обработать до мягкой консистенции или нарезать тонкими ломтиками.

- Пища этого этапа - фрукты, овощи, бобовые, мясо, печень, желток, небольшие количества рыбы, кисломолочные продукты (творог, кефир)

- Частота приема пищи 3-4 раза в день

- Кормление грудью продолжается по требованию

- Параллельно с едой ребенку можно предложить питье из чашки: лучше, если это вода.

\section{Продукты, вводимые с 8-10 месяцев:}

1. Желток - в виде сваренного вкрутую, дается 2 раза в неделю. Первый раз - несколько крупинок. Второй раз - 1/4 желтка. На следующей неделе можно дать половину куриного желтка. В таком количестве и продолжать давать 2 раза в неделю. Его проще растирать с грудным молоком или добавлять в кашу или овощное пюре.

2. Рыба - 1-2 раза в неделю в количестве 30-60 $\Gamma$ в качестве альтернативы мясу сельскохозяйственных животных. Начинать лучше с нежирных сортов: треска, хек, минтай, камбала. Эти сорта рыбы являются низкоаллергенными и нежирными.

3. Кисломолочные продукты - кефир, детский йогурт начиная с 5-10 мл постепенно увеличивая до 100-150 мл в сутки. Давать вечером за несколько часов до ужина.

4. Творог - без всяких добавок, сахара и фруктов. Допустимый объем в сутки: с 9 мес - 30 г, к 12 мес - 50 г. Вводится медленно. Фруктовые добавки к творогу - с 10 месяцев.

5. Хлеб - сухарик из пшеничного хлеба, сушки, несладкое печенье
Четвертый этап: 10-12 месяцев. Это последние месяцы введения прикорма, когда взрослые все еще дают ребенку пищу, специально приготовленную для него.

- Грудное молоко продолжает составлять важную часть рациона питания и предпочтительно должно быть главной жидкостью. Продукты на этом этапе должны быть рублеными или размятыми, а мясо прокручено на мясорубке, измельчено блендером.

- В каждый прием пищи включаются продукты, которые можно брать пальцами: маленькие кубики фруктов, овощей, картофеля, сыра и мягкого мяса, чтобы приучать ребенка есть самостоятельно и определять консистенцию продуктов, но под пристальным присмотром взрослого, потому что ребенок может подавиться.

- К возрасту примерно 1 или 1.5 года дети могут есть обычную пищу с семейного стола и не требуют специально приготовленных блюд ${ }^{6}$. По-прежнему не рекомендуется добавлять соль.

\section{Хорошую переносимость прикорма} оценивают по: отсутствию срыгиваний, отсутствию изменений со стороны стула (как по частоте, так и по качеству), отсутствию кожных изменений, адекватной прибавке в весе, положительной динамике нервно-психического развития ребенка.

\section{Основные рекомендации по введению прикорма}

- грудное молоко в течение всего периода введения прикорма остается главным видом пищи, потребляемой грудным ребенком

- продолжать кормление грудью по требованию

- ребенку, находящемуся на полноценном грудном вскармливании начинать вводить прикорм с 5,5-6-ти месячного возраста

- соки и фрукты не должны быть одним из основных прикормов, тем более первым, т.к. являются низкокалорийными, могут вызывать расстройства кишечника, аллергические реакции, вытесняют грудное молоко

- первым прикормом должны быть безмолочные безглютеновые каши или 
овощные пюре приготовленные на основе воды или с добавлением материнского молока

- можно добавлять в прикорм сцеженное грудное молоко для облегчения привыкания к новой пище

- начинать прикорм надо - с однородного, умеренной густоты однокомпонентного пюре или каши. Постепенно переходить к более густой, затем - к более плотной пище, приучая ребенка к жеванию и приему пищи с ложки. С 9 - 10 мес - давать прикормы, в составе которых имеются мягкие кусочки пищи

- после привыкания к однокомпонентному пюре/каше постепенно вводить прикормы многокомпонентные (каши из смеси злаков, пюре из нескольких овощей)

- каждый новый продукт вводиться с интервалом в одну неделю

- увеличивать объем прикорма по мере роста ребенка, начиная с одной чайной ложки, постепенно (за 7 дней) доводя до полного объема. Максимальный объем блюд прикорма для ребенка первого года жизни 150-200 г

- не заставлять ребенка доедать прикорм, если он не съедает всю порцию, значит ему хватает меньшего количества

- постепенно увеличивать число кормлений в день: 2-3 раза в возрасте 6-8 месяцев, 3-4 раза в возрасте - 8-10 месяцев, 3-4 основных приема и 2 закуски - в возрасте старше 10 месяцев

- не использовать цельное коровье молоко в питании ребенка до 1 года

- чтобы повысить калорийность каши или овощного пюре можно добавлять Грудное молоко или искусственную смесь. Или добавить не более 1 ч.л. растительного или сливочного масла (топленого), если объем прикорма больше 100 г. Масло вводят сначала растительное, потом сливочное

- вводить прикорм лучше после непродолжительного кормления грудью, а после съеденного прикорма предложить грудь, чтобы "докормить" или напоить

- прикорм вводят, когда ребенок здоров. Не рекомендуется вводить в рацион новые блюда и продукты прикорма при острых заболеваниях, либо изменениях условий жизни младенца (поездки, переезды, смена ухаживающих лиц), в период проведения профилактических прививок

- для введения прикорма выбрать наиболее подходящее время дня (когда ребенок голоден или наиболее предрасположен к приему пищи). Предпочтительна первая половина дня, чтобы отметить возможную реакцию на его введение: поведение ребенка, характер стула, состояние кожного покрова.

избегать добавления в прикорм сахара, специй и соли

Финансовый источник: При написании статьи не использовались финансовые ресурсы.

Конфликт интересов: Нет.

\section{СПИСОК ЛИТЕРАТУРЫ}

1. Kim Fleischer Michaelsen, Lawrence Weaver. Francesco Branca. Aileen Robertson Кормление и питание грудных детей и детей раннего возраста, 2001, с.220

2. В.Ю Альбицкий. Руководство по амбулаторно-поликлинической педиатрии, Москва, с. 75, 2009

3. Консультирование по вопросам кормления детей грудного и раннего возраста: сводный курс. Пособие для слушателя стр. 185

4. http://www.who.int/features/qa/21/ru/

5. Guiding principles for complementary feedng of the breastfed child, Pan American Health Organization, WHO, 37 p., 2001

6. Kim Fleischer Michaelsen. Lawrence Weaver. Francesco Branca. Aileen Robertson, Кормление и питание грудных детей и детей раннего возраста. 2001, с. 232,

7. Kim Fleischer Michaelsen. Lawrence Weaver. Francesco Branca. Aileen Robertson, Кормление и питание грудных детей и детей раннего возраста. 2001, стр.241

8. Н.Бате, К. Кобб и др. Рекомендации по питанию детей грудного и раннего возраста (программа Start Healthy-расти здоровым с первых дней). Вопросы современной педиатрии, том 6. № 1, 2007. 